\title{
Pengaruh Corporate Social Responsibility (CSR) Terhadap Profitabilitas Pada Perusahaan Perbankan Yang Terdaftar di BEI
}

\author{
Aliah Pratiwi \\ STIE Bima, Indonesia \\ aliahpratiwi@ymail.com
}

\author{
Nafisah Nurulrahmatia \\ STIE Bima, Indonesia \\ nafisahrachmatia@gmail.com
}

\author{
Puji Muniarty \\ STIE Bima, Indonesia \\ Puji.stiebima@gmail.com
}

\begin{abstract}
ABSTRAK
Penelitian ini bertujuan untuk mengetahui pengaruh pengungkapan Corporate Sosial Responsibility (CSR) terhadap profitabilitas yang di proxy kan dengan Return On Asset (ROA) dan Return On Equity (ROE) pada perusahaan perbankan yang terdaftar di BEI. Corporate social responsibility (CSR) merupakan suatu konsep terintegrasi yang menggabungkan aspek bisnis dan sosial dengan selaras agar perusahaan dapat membantu tercapainya kesejahteraan para stakeholder, serta dapat meningkatkan profit perusahaan. Penelitian ini dilakukan pada perusahaan perbankan yang terdaftar di BEI dengan menggunakan laporan tahunan (annual report) tahun 2017-2018. Sampel dalam penelitian ini adalah Bank BUMN yang terdaftar di BEI sebanyak 4 perbankan yaitu Bank Negara Indonesia Tbk, Bank Rakyat Indonesia Tbk, Bank Mandiri Tbk dan Bank Tabungan Negara Tbk. Penentuan sampel diambil menggunakan teknik purposive sampling yaitu sampel yang diambil berdasarkan kriteria yang ditentukan dari peneliti. Data yang digunakan adalah data sekunder yang di peroleh dari www.idx.co.id. Pengungkapan CSR berpedoman pada Global Reporting Initiative (GRI) generasi empat atau disebut G4 dengan 74 indeks. Metode analisis data yang digunakan dalam penelitian ini adalah model regresi panel. Pengolahan data menggunakan aplikasi Eviews 10. Adapun hasil dari penelitian ini adalah Corporate Social Responsibility (CSR) tidak memiliki pengaruh yang signifikan terhadap Return On Asset (ROA) hal ini terlihat dari nilai probabilitas $>0,05$ yaitu 0,296 dan Corporate Social Responsibility (CSR) tidak memiliki pengaruh yang signifikan terhadap Return On Equity (ROE) karena nilai probabilitasnya $>0,05$ yaitu 0,72. Kesimpulannya bahwa Corporate Social Responsibility (CSR) tidak berpengaruh signifikan terhadap profitabilitas dalam hal ini di ukur dengan ROA dan ROE. Saran bagi peneliti selanjutnya adalah diharapkan menggunakan rasio keuangan lainnya, menggunakan variabel moderating dan menggunakan periode penelitian yang berbeda.
\end{abstract}

\section{Kata Kunci : Corporate Social Responsibility, Return On Asset, Return On Equity}

\section{Pendahuluan}

Pada saat ini perusahaan dituntut untuk dapat terus bersaing dan menerapkan strategi yang telah ditetapkan. Salah satu cara yang dilakukan oleh perusahaan adalah dengan melakukan aktivitas yang memberikan manfaat tidak hanya bagi perusahaan, tetapi memiliki dampak positif bagi masyarakat sebagai bagian dari stakeholders. Salah satu dampak positif bagi perusahaan adalah ketika perusahaan melakukan kegiatan Corporate Social Responsibility.

Perbankan merupakan salah satu tonggak perekonomian di Indonesia, dikarenakan bank memiliki peran penting dalam usaha penyaluran dana untuk berbagai kepentingan yang secara langsung berhubungan dengan berbagai komunitas lingkungan masyarakat. Bank diharuskan tidak hanya menjalankan tugasnya dalam bidang perbankan, namun wajib memberikan 
bukti kepedulian terhadap komunitas yang secara langsung berhubungan dengan kegiatan operasinya. Salah satu bentuk kepedulian tersebut adalah program Corporate Social Responsibility.

Praktik

Corporate Social Responsibility (CSR) yang dilakukan oleh perusahaan-perusahaan telah mengalami perubahan dari waktu ke waktu. ${ }^{(23)}$ Saat industri berkembang setelah terjadinya revolusi industri, banyak perusahaan yang masih memfokuskan dirinya sebagai suatu organisasi yang hanya mencari keuntungan belaka. Di Indonesia sendiri, praktik CSR mulai banyak dilakukan oleh perusahaan di akhir tahun 1990-an yang dimulai dengan dikeluarkannya UU. No. 23 tahun 1997 tentang pengelolaan lingkungan hidup (UUPLH) pasal 41 ayat (1), dengan ditetapkannya undang-undang tersebut, walau memang belum mewajibkan perusahaan untuk melakukan kegiatan CSR, dan kegiatan CSR yang dilakukanpun masih merupakan kegiatan yang terbatas karena bersifat sukarela. Namun, setidaknya undang-undang tersebut membuka harapan bahwa nantinya dapat membuat perusahaan tidak melakukan berbagai macam kegiatan usaha yang dapat mencemari lingkungan.

Pemerintah mengeluarkan peraturan tentang CSR yang baru, yaitu UU. No. 40 tahun 2007. Undang-undang tersebut menjelaskan bahwa setiap perseroan yang menjalankan kegiatan usahanya di bidang dan/atau berkaitan dengan sumber daya alam wajib melaksanakan tanggung jawab sosial dan lingkungan. Barang siapa perseroan yang tidak melakanakan kewajiban tersebut akan dikenai sanksi sesuai dengan ketentuan perundang-undangan yang berlaku. Dengan ditetapkannya peraturan tersebut, maka setiap perusahaan yang melakukan kegiatan usahanya di bidang dan/atau yang berkaitan dengan pemanfaatan sumber daya alam, wajib melakukan kegiatan CSR. Dengan berlakunya peraturan baru tersebut, kegiatan CSR kini bukan lagi hanya bersifat sukarela, namun telah menjadi sebuah kewajiban bagi perusahaan ${ }^{(6)}$.

Banyak manfaat yang diperoleh perbankan dengan pelaksanaan tanggung jawab social atau corporate social responsibility, antara lain produk perbankan yang ditawarkan semakin diminati oleh masyarakat dan perusahaan disukai oleh investor. Selain itu, Corporate social responsibility dapat digunakan sebagai alat marketing model baru bagi perusahaan bila itu dilaksanakan secara jangka panjang atau berkelanjutan. Untuk melaksanakan berbagai kegiatan CSR berarti perusahaan harus mengeluarkan sejumlah biaya, dan biaya pada akhirnya akan menjadi beban yang harus ditanggung oleh perusahaan sehingga mengurangi pendapatan, dan mengakibatkan tingkat profit perusahaan akan mengalami penurunan. Akan tetapi, sisi baik dengan melaksanakan kegiatan CSR, citra perusahaan akan semakin baik di mata masyarakat, sehingga loyalitas masyarakat terhadap perusahaan akan semakin tinggi.

Dari uraian diatas dapat memberikan bukti bahwa terdapat suatu hubungan antara praktik kegiatan CSR, dengan strategi perusahaan dalam meningkatkan profitabilitas bagi perusahaan. Dengan perusahaan melakukan praktik CSR, secara tidak langsung hal tersebut menjadi salah satu kegiatan promosi yang dilakukan perusahaan terhadap masyarakat dan para investor. Perusahaan akan menarik hati masyarakat dan investor dengan kegiatan-kegiatan sebagai bentuk tanggungjawab terhadap lingkungan. Selain itu, aktivitas CSR perusahaan dapat diakui sebagai suatu investasi jangka panjang perusahaan di dalam mengembangkan produk perbankan. Bank Dunia menyatakan bahwa tanggung jawab sosial terdiri dari beberapa komponen utama: perlindungan lingkungan, jaminan kerja, hak azasi manusia, interaksi dan keterlibatan perusahaan dengan masyarakat, standar usaha, pasar, pengembangan ekonomi dan badan usaha, perlindungan kesehatan, kepemimpinan dan pendidikan, bantuan bencana kemanusiaan. Namun saat sekarang masih banyak perusahaan yang tidak ingin melaksanakan kegiatan CSR karena mereka menganggap bahwa kegiatan CSR membutuhkan dana yang besar sehingga akan mengurangi laba yang diperoleh perusahaan.

Masalah tanggung jawab sosial perusahaan kepada lingkungan social semakin banyak disoroti, maka penelitian ini dimaksudkan untuk menganalisis pengaruh kepedulian sosial perusahaan perbankan yang 
terdaftar di Bursa Efek Indonesia terhadap profit yang dihasilkannya. Biaya-biaya sosial sebagai wujud pelaksanaan CSR perusahaan dikaitkan dengan profitabilitas perusahaan, terutama pada return yang akan diterima perusahaan.

Beberapa literatur penelitian yang ditemukan kontradiksi teoritis yaitu ${ }^{(8)}$ Dalam penelitian ini diperoleh hasil bahwa CSR berpengaruh signifikan terhadap ROA dan ROE. Penelitian ini sejalan dengan penelitian (13) Dalam penelitian ini menyatakan bahwa CSR yang di proksikan dengan biaya kesejateraan karyawan dan biaya komunitas memiliki pengaruh terhadap profitabilitas yang di proksikan dengan ROA. Begitu pula dengan penelitian ${ }^{(14)}$ Hasil penelitian yang dilakukan menunjukkan bahwa CSR berpengaruh signifikan terhadap ROA, ROE dan EPS.

Berbeda dengan penelitian (4) menemukan bahwa CSR tidak berpengaruh signifikan terhadap ROA dan ROE. Hal ini sejalan dengan penelitian (6) menemukan bahwa Variabel Corporate Social Responsibility (CSR) memiliki hubungan positif dengan profitabilitas perusahaan yang diproksikan dengan Return On Assets (ROA), Return on Equity (ROE), Earning per Share (EPS), dan Net Profit Margin (NPM). Tetapi, hanya dengan proksi Net Profit Margin (NPM) variabel Corporate Social Responsibility (CSR) dapat mempengaruhi profitabilitas perusahaan secara signifikan sedangkan Return On Assets (ROA), Return on Equity (ROE) tidak berpengaruh signifikan.

Perbedaan penelitian terdahulu dengan penelitian sekarang adalah terkait obyek penelitian, periode waktu penelitian dan variabel yang digunakan. Dari beberapa permasalahan dan perbedaan penelitian diatas maka peneliti mencoba untuk melakukan penelitian pada sektor yang berbeda untuk lebih memperbanyak referensi teori. Dengan demikian dapat dirumuskan permasalahannya: Apakah Corporate Social Responsibility (CSR) berpengaruh terhadap Return On Assets (ROA) dan Return On Equity (ROE) pada Perbankan yang terdaftar di BEI?

\section{Landasan Teori}

1. Corporate Social Resposibility (CSR)

(4) Menurut Hackston dan Milne (1996), pengungkapan tanggung jawab sosial perusahaan sering disebut juga sebagai Corporate Social Responsibility Disclosure yang merupakan proses pengkomunikasian dampak sosial dan lingkungan dari kegiatan ekonomi organisasi terhadap kelompok khusus yang berkepentingan dan terhadap masyarakat secara keseluruhan. Pengungkapan tanggung jawab sosial juga dapat diartikan sebagai tanggung jawab moral suatu perusahaan terhadap strategi stakeholder, terutama komunitas dan masyarakat sekitar wilayah kerja dan operasinya. Tujuan pengungkapan tanggung jawab sosial perusahaan menurut Gray et al (1998) adalah: 1) Untuk meningkatkan image perusahaan 2) Untuk meningkatkan akuntabilitas suatu organisasi, dengan asumsi bahwa terdapat kontrak sosial antara organisasi dengan masyarakat. 3) Untuk memberikan informasi kepada investor

CSR (corporate social responsibility) dimaknai sebagai komitmen perusahaan atau organisasi untuk terus menerus bertindak secara etis, beroperasi secara legal dan berkontribusi untuk peningkatan ekonomi, bersamaan dengan peningkatan kualitas hidup dari karyawan dan keluarganya sekaligus juga peningkatan kualitas komunitas lokal dan masyarakat secara lebih luas (16). CSR merupakan bentuk pembangunan keberlanjutan perusahaan dengan bertanggungjawab terhadap sosial, ekonomi, dan lingkungan perusahaan akibat dari aktivitas operasional yang dilakukan perusahaan. Melalui pelaksanaan CSR diharapkan mampu memberikan dampak positif terhadap ekonomi, sosial dan lingkungan perusahaan ${ }^{(21)}$

(23) Menguraikan pelaksanaan Corporate Social Responsibility perusahaan tidak hanya dilakukan oleh perusahaan yang bergerak di sektor industri yang memiliki dampak negatif terhadap lingkungan dan masyarakat sekitarnya, tetapi juga sektor lain seperti jasa, asuransi, komunikasi, lembaga keuangan bank dan bukan bank. Corporate Social Responsibility bank tidak hanya dilihat sebagai tanggungjawab, namun memiliki 
manfaat yang besar bagi kelangsungan organisasi perbankan itu sendiri.

CSR menurut Global Reporting Initiative memiliki enam kategori diantaranya kinerja ekonomi, kinerja lingkungan, ketenagakerjaan, hak asasi manusia, masyarakat sosial, dan tanggung jawab produk. Masing-masing kategori memiliki item-item yang secara keseluruhan jumlah item pada pengungkapan CSR terdapat 65-78 item. Pertama, untuk mendapatkan data CSR perlu dilakukannya analisis laporan tahunan perusahaan. Item CSR yang diungkapkan pada laporan tahunan perusahaan diberi skor 1 dan untuk CSR yang itemnya tidak diungkapkan perusahaan pada laporan keuangannya diberi skor 0. Kedua, item-item yang telah terkumpul dilakukan perhitungan untuk mendapatkan nilai CSR Index nya dengan menggunakan rumus total item yang diperoleh dibagi dengan total item secara keseluruhan.

(7) Manfaat Corporate Social Responsibility bagi masyarakat adalah sebagai berikut:

a. Meningkatnya kesejahteraan masyarakat sekitar dan kelestarian lingkungan.

b. Adanya beasiswa untuk anak tidak mampu di daerah tersebut.

c. Meningkatnya pemeliharaan fasilitas umum.

d. Adanya pembangunan desa atau fasilitas masyarakat yang bersifat social dan berguna untuk masyarakat banyak khususnya masyarakat yang berada di sekitar perusahaan tersebut berada.

Sedangkan manfaat Corporate Social Responsibility bagi perusahaan adalah:

a. Mempertahankan dan mendongkrak reputasi serta citra merek perusahaan.

b. Mendapatkan lisensi untuk beroperasi secara sosial.

c. Mereduksi resiko bisnis perusahaan.

d. Melebarkan akses sumberdaya bagi operasional perusahaan

e. Mereduksi biaya misalnya terkait dampak pembuangan limbah

f. Memperbaiki hubungan dengan stakeholders

2. Profitabilitas

Profitabilitas perusahaan merupakan usaha perusahaan untuk mendapatkan keuntungan dalam kurun waktu tertentu. Profitabilitas perusahaan adalah salah satu landasan penilaian yang mencerminkan keadaan/kondisi perusahaan. Dalam menilai kondisi tersebut dibutuhkan alatalat analisis serta dasar teori yang kuat. Alat-alat analisis yang dimaksud yaitu rasio-rasio keuangan (rasio profitabilitas). ${ }^{(17)}$ Rasio profitabilitas merupakan suatu model analisis yang berupa perbandingan data keuangan sehingga informasi keuangan tersebut menjadi lebih berarti. Hasil pengukuran tersebut dapat dijadikan alat evaluasi kinerja manajemen perusahaan. Untuk perusahaan yang belum mencapai target finansial seperti yang telah ditentukan artinya mereka perlu memperbaiki lagi keefektifan dalam produktivitas kerja mereka.

Profitabilitas adalah hasil akhir bersih dari berbagai kebijakan dan keputusan yang dilakukan oleh perusahaan ${ }^{(1)}$, dimana rasio ini digunakan sebagai alat pengukur atas kemampuan perusahaan untuk memperoleh keuntungan. Dengan demikian pengukuran profitabilitas suatu perusahaan menunjukkan tingkat efektifitas manajemen secara menyeluruh dan secara tidak langsung para investor jangka panjang akan sangat berkepentingan dengan analisis ini. Selain itu keuntungan (profitabilitas) sangat penting bagi perusahaan bukan saja untuk terus mempertahankan pertumbuhan bisnisnya namun juga memperkuat kondisi keuangan perusahaan.

Adapun indikator yang digunakan untuk mengukur profitabilitas diantaranya adalah:
a. Gross Profit Margin
b. Operating Profit Margin
c. Net Profit Margin
d. Return On Assets
e. Return On Equity
f. Return On Investment
g. Earning Per Share

Dalam penelitian ini penulis hanya menggunakan dua indikator pengukuran profitabilitas, yaitu:

1. ROA (Return On Assets)

ROA (Return On Assets) adalah ROA (Return On Assets) merupakan pengukuran kemampuan perusahaan secara keseluruhan di dalam menghasilkan keuntungan dengan jumlah keseluruhan aktiva yang tersedia di dalam perusahaan. Semakin tinggi rasio ini, semakin baik keadaan suatu perusahaan ${ }^{(20)}$. 
Rasio ini melihat sejauh mana investasi yang telah ditanamkan mampu memberikan pengembalian keuntungan sesuai dengan yang diharapkan. Dan investasi tersebut sebenarnya sama dengan asset perusahaan yang ditanamkan atau ditempatkan. Semakin tinggi tingkat laba maka akan semakin tinggi pula Return On Assetnya (ROA), karena hasil pengembalian terhadap jumlah harta dapat dipergunakan untuk mengukur efektifitas perusahaan dalam memanfaatkan seluruh sumber daya yang ada dalam perusahaan ${ }^{(2)}$.

${ }^{(5)}$ Return on Asset (ROA) merupakan salah satu rasio untuk mengukur keberhasilan suatu perusahaan dalam menggunakan asetnya untuk menghasilkan laba. CSR merupakan salah satu kegiatan yang perusahaan jalankan dalam mempergunakan asetnya untuk menghasilkan laba. Walaupun banyak biaya yang dikeluarkan dalam merealisasikannya, namun CSR diyakini sebagai usaha perusahaan dalam menciptakan laba jangka panjang. Laba yang dimaksud adalah investasi perusahaan berupa brand image yang positif pada mindset masyarakat. Untuk itu, rasio profitabilitas ROA dikatakan memiliki hubungan yang relevan dengan CSR. Berikut adalah rumus ROA:

$$
\mathrm{ROA}=\frac{\text { Net Income }}{\text { Total Assets }}
$$

\section{ROE (Return On Equity)}

ROE (Return On Equity) adalah rasio laba bersih terhadap ekuitas. Rasio yang mengukur kemampuan perusahaan menghasilkan laba berdasarkan modal saham tertentu. Dibeberapa referensi disebut juga dengan rasio total asset turnover atau perputaran total asset ${ }^{(3)}$.

ROE (Return On Equity) merupakan suatu pengukuran dari penghasilan (income) yang tersedia bagi para pemilik perusahaan (baik pemegang saham biasa maupun pemegang saham preferen) atas modal yang mereka investasikan di dalam perusahaan. Secara umum tentu saja semakin tinggi return atau penghasilan yang diperoleh semakin baik kedudukan pemilik perusahaan.

Rasio ini menunjukkan perbandingan laba bersih dengan total ekuitas. Rasio Return On Equity dapat dihitung dengan formula:

$$
\mathrm{ROE}=\frac{\text { Net Income }}{\text { Total Equity }}
$$

${ }^{\left({ }^{9}\right)}$ Tujuan penggunaan rasio profitabilitas bagi perusahaan maupun bagi pihak luar perusahaan, adalah : 1) Untuk menghitung atau mengukur laba yang diperoleh perusahaan dalam satu periode tertentu. 2) Untuk menilai posisi laba perusahaan tahun sebelumnya dengan tahun sekarang. 3) Untuk menilai besarnya laba bersih sesudah pajak dengan modal sendiri. 4) Untuk menilai perkembangan laba dari waktu ke waktu. 5) Untuk mengukur produktivitas seluruh dana perusahaan yang digunakan baik modal pinjaman maupun modal sendiri.

Gambar 1 Kerangka Pikir Penelitian

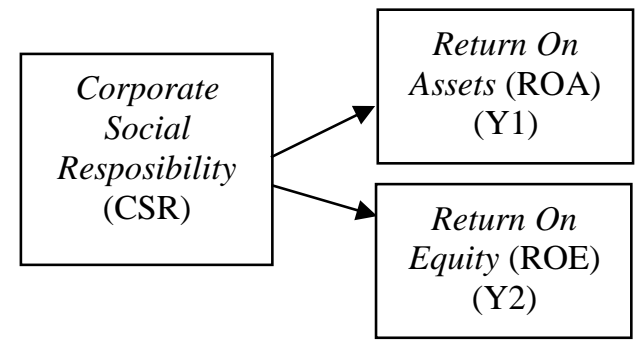

Pengaruh pengungkapan Corporate Social Responsibility terhadap ROA

Dengan melakukan aktivitas CSR perusahaan dapat meningkatkan kepercayaan masyarakat terhadap produk perusahaan sehingga reputasi perusahaan juga meningkat dimata masyarakat. Akibatnya masyarakat semakin mengenal produk perusahaan dan berkeinginan untuk menggunakan produknya. Semakin produk laku dipasaran maka laba perusahaan akan semakin meningkat. Dengan demikian laba yang meningkat akan mempengaruhi ROA suatu perusahaan.

Semakin tinggi ROA maka semakin baik produktivitas aset dalam memperoleh keuntungan bersih. Akibatnya akan meningkatkan daya tarik investor kepada perusahaan karena tingkat pengembalian atau deviden akan semakin besar. Berdasarkan uraian diatas maka dapat dirumuskan hipotesis:
H1 : Corporate Social Responsibility (CSR) berpengaruh terhadap Return On Assets (ROA) 
Pengaruh pengungkapan Corporate Social Responsibility terhadap ROE

ROE merupakan rasio yang digunakan untuk mengukur profitabilitas perusahaan. Angka ROE yang tinggi akan membawa keberhasilan bagi perusahaan yang mengakibatkan tingginya harga saham dan membuat perusahaan mudah menarik dana baru ${ }^{(22)}$. CSR merupakan salah satu stategi perusahaan untuk mencapai tujuan perusahaan. Dengan melakukan aktivitas CSR perusahaan akan mendapat citra baik dari masyarakat. Jika perusahan bisa menciptakan citra baik dan kepercayaan masyarakat maka diharapkan mampu menimbulkan loyalitas konsumen. Loyalitas konsumen akan meningkatkan penjualan yang berdampak pada kenaikan laba. Salah satu alat untuk mengukur profitabilitas dengan melihat tingkat ROE.

Laba yang tinggi akan berdampak pada ROE yang tinggi. Investor akan menjadikan ROE yang tinggi sebagai salah satu pertimbangan untuk menanamkan modalnya pada perusahaan. Berdasarkan uraian diatas, maka hipotesis yang dapat dirumuskan adalah :

H2 : Corporate Social Responsibility (CSR) berpengaruh terhadap Return On Equity (ROE)

\section{Metode}

Berdasarkan objek dan tujuan yang telah ditetapkan maka penelitian ini menggunakan jenis penelitian penjelasan (explanatory research). ${ }^{(18)}$ Sebagaimana yang telah dituliskan bahwa explanatory research digunakan untuk menjelaskan hubungan kausal yang terjadi antara variabel-variabel penelitian melalui pengujian hipotesa untuk mengetahui adanya pengaruh antara variabelvariabel yang diteliti. Sumber Data dalam penelitian ini adalah data yang dipublikasikan melalui website Bursa Efek Indonesia (www.idx.co.id).

(18) Populasi merupakan wilayah generalisasi yang terdiri dari objek atau subjek yang mempunyai kualitas dan karakteristik tertentu yang ditetapkan oleh peneliti untuk dipelajari dan kemudian ditarik kesimpulan. Gambaran dari populasi yang dijadikan objek penelitian ini adalah perusahaan perbankan yang terdaftar di BEI.
Jenis penelitian ini adalah penelitian empiris yang menggunakan data kuantitatif yang dipublikasikan melalui website (www.idx.co.id) berupa laporan tahunan perbankan 2017-2018. Populasi dalam penelitian ini adalah perusahaan perbankan yang terdaftar di Bursa Efek Indonesia pada tahun 2017-2018 berjumlah 43 perusahaan. Sampel adalah bagian dari jumlah dan karakteristik yang dimiliki oleh populasi tersebut. (18) Sampel dalam penelitian ini adalah Bank BUMN yang terdaftar di BEI sebanyak 4 perbankan yaitu Bank Negara Indonesia Tbk, Bank Rakyat Indonesia Tbk, Bank Mandiri Tbk dan Bank Tabungan Negara Tbk. Penentuan sampel diambil menggunakan teknik purposive sampling yaitu sampel yang diambil berdasarkan kriteria yang ditentukan dari peneliti.

Pengungkapan CSR berpedoman pada Global Reporting Initiative (GRI) generasi empat atau disebut G4 dengan 74 indeks pengungkapan CSR, Informasi mengenai Corporate Social Responsibility berdasarkan GRI terdiri dari 3 fokus pengungkapan, yaitu sosial, ekonomi, dan lingkungan. Dengan rumus :

$$
\operatorname{CSRj}=\frac{\sum X i j}{N i j}
$$

Keterangan :

$\mathrm{CSRj}=$ Corporate Social Responsibility Disclosure Index perusahaan

$\sum \mathrm{Xij}=$ Jumlah pengungkapn $\mathrm{CSR}$ perusahaan

$\mathrm{Nij}=$ Jumlah item untuk perusahaan sebesar 74 indikator

Variabel dependen yang digunakan adalah Return on Assets (ROA) dengan formula (Laba bersih/ total asset), Return on equity (ROE) dengan formula (laba bersih/ total ekuitas).

Model regresi panel adalah metode analisis data yang akan digunakan dalam penelitian ini. Regresi panel merupakan perpaduan antara data silang tempat (cross section) dengan data runtun waktu (time series). Aplikasi yang tepat dalam menggunakan teknik regresi panel adalah menggunakan aplikasi Eviews. Beberapa metode yang digunakan dalam mengestimasi 
model regresi data panel, yaitu pooling least square (Common Effect), pendekatan efek tetap (Fixed Effect), pendekatan efek random (Random Effect).

\section{Hasil dan Pembahasan}

Berdasarkan pengujian data di peroleh hasil bahwa Corporate Social Responsibility (CSR) tidak memiliki pengaruh yang signifikan terhadap Return On Asset (ROA).

Hasil pengujian yang telah dilakukan pada Uji Chow Test, Uji Hausman Test, dan Uji LM Test telah didapat bahwasanya model terbaik untuk menjawab hipotesis pada variabel dependen Y1 (ROA) adalah model Random Effect. Hasil pengujian hipotesis pada dependen Y1 dengan model Random Effect adalah sebagai berikut:

\section{TABEL 1 UJI RANDOM EFFECT MODEL}

\begin{tabular}{|c|c|c|c|c|}
\hline \multicolumn{5}{|c|}{$\begin{array}{l}\text { Dependent Variable: ROA } \\
\text { Method: Panel EGLS (Cross-section random effects) } \\
\text { Date: } 12 / 08 / 19 \text { Time: } 23: 13 \\
\text { Sample: } 20172018 \\
\text { Periods included: } 2 \\
\text { Cross-sections included: } 4 \\
\text { Total panel (balanced) observations: } 8 \\
\text { Swamy and Arora estimator of component variances }\end{array}$} \\
\hline Variable & Coefficient & Std. Error & t-Statistic & Prob. \\
\hline$\stackrel{C}{C S R}$ & $\begin{array}{r}0.042898 \\
-0.033709\end{array}$ & $\begin{array}{l}0.021281 \\
0.029456\end{array}$ & $\begin{array}{r}2.015816 \\
-1.144368\end{array}$ & $\begin{array}{l}0.0904 \\
0.2961\end{array}$ \\
\hline \multicolumn{5}{|c|}{ Effects Specification } \\
\hline $\begin{array}{l}\text { Cross-section randon } \\
\text { Idiosyncratic random }\end{array}$ & & & $\begin{array}{l}0.005915 \\
0.001324\end{array}$ & $\begin{array}{l}0.9523 \\
0.0477\end{array}$ \\
\hline \multicolumn{5}{|c|}{ Weighted Statistics } \\
\hline $\begin{array}{l}\text { R-squared } \\
\text { Adjusted R-squared } \\
\text { S.E. of regression } \\
\text { F-statistic } \\
\text { Prob(F-statistic) }\end{array}$ & $\begin{array}{l}0.191010 \\
0.056178 \\
0.001273 \\
1.416655 \\
0.278908\end{array}$ & \multicolumn{2}{|c|}{$\begin{array}{l}\text { Mean dependent var } \\
\text { S.D. dependent var } \\
\text { Sum squared resid } \\
\text { Durbin-Watson stat }\end{array}$} & $\begin{array}{l}0.002936 \\
0.001310 \\
9.72 \mathrm{E}-06 \\
1.775713\end{array}$ \\
\hline \multicolumn{5}{|c|}{ Unweighted Statistics } \\
\hline $\begin{array}{l}\text { R-squared } \\
\text { Sum squared resid }\end{array}$ & $\begin{array}{l}0.237118 \\
0.000182\end{array}$ & $\begin{array}{l}\text { Mean depend } \\
\text { Durbin-Watso }\end{array}$ & $\begin{array}{l}\text { ent var } \\
\text { n stat }\end{array}$ & $\begin{array}{l}0.018788 \\
0.094576\end{array}$ \\
\hline
\end{tabular}

Suatu variabel bebas (X) dikatakan berpengaruh signifikan terhadap variabel terikatnya (Y) apabila nilai yang dihasilkan < 0,05 . Berdasarkan output yang ditampilkan pada Tabel 1 diatas, dapat dilihat bahwa nilai probabilitas > 0,05 yaitu sebesar 0,296. Nilai $R$-Squared untuk variabel dependen ROA sebesar 0.191 lebih kecil dari 0.5, maka menunjukkan korelasi atau hubungan antara variable Corporate Social Responsibility dan ROA adalah lemah. Profitabilitas yag diukur dengan variabel dependen ROA dapat dijelaskan oleh variabel CSR hanya 19,1\%. Maka peneliti dapat menjawab hipotesis dari variabel Y1 (ROA) sebagai berikut:

H1: Corporate Social Responsibility (CSR) tidak memiliki pengaruh yang signifikan terhadap Return On Asset (ROA)

Sementara itu berdasarkan pengujian data di peroleh hasil bahwa Corporate Social Responsibility (CSR) tidak memiliki pengaruh yang signifikan terhadap Return On Equity (ROE).

Hasil pengujian yang telah dilakukan pada Uji Chow Test, Uji Hausman Test, dan Uji LM Test telah didapat bahwasanya model terbaik untuk menjawab hipotesis, pada variabel dependen Y2 (ROE) adalah model Fixed Effect. Berikut adalah tampilan dari hasil model Fixed Effect untuk variabel dependen Y2 (ROE).

\section{TABEL 2 UJI FIXED EFFECT MODEL}

\begin{tabular}{|c|c|c|c|c|}
\hline \multicolumn{5}{|c|}{$\begin{array}{l}\text { Dependent Variable: ROE } \\
\text { Method: Panel Least Squares } \\
\text { Date: } 12 / 08 / 19 \text { Time: } 23: 28 \\
\text { Sample: } 20172018 \\
\text { Periods included: } 2 \\
\text { Cross-sections included: } 4 \\
\text { Total panel (balanced) observations: } 8\end{array}$} \\
\hline Variable & Coefficient & Std. Error & t-Statistic & Prob. \\
\hline C & 0.210861 & 0.178243 & 1.182999 & 0.3220 \\
\hline CSR & -0.094769 & 0.249142 & -0.380381 & 0.7290 \\
\hline \multicolumn{5}{|c|}{ Effects Specification } \\
\hline \multicolumn{5}{|c|}{ Cross-section fixed (dummy variables) } \\
\hline $\begin{array}{l}\text { R-squared } \\
\text { Adjusted R-squared } \\
\text { S.E. of regression } \\
\text { Sum squared resid } \\
\text { Log likelihood } \\
\text { F-statistic } \\
\text { Prob(F-statistic) }\end{array}$ & $\begin{array}{l}0.890340 \\
0.744126 \\
0.010368 \\
0.000323 \\
29.12370 \\
6.089296 \\
0.084812\end{array}$ & \multicolumn{2}{|c|}{$\begin{array}{l}\text { Mean dependent var } \\
\text { S.D. dependent var } \\
\text { Akaike info criterion } \\
\text { Schwarz criterion } \\
\text { Hannan-Quinn criter. } \\
\text { Durbin-Watson stat }\end{array}$} & $\begin{array}{r}0.143075 \\
0.020498 \\
-6.030925 \\
-5.981274 \\
-6.365801 \\
3.200000\end{array}$ \\
\hline
\end{tabular}

Suatu variabel bebas (X) dikatakan berpengaruh signifikan terhadap variabel terikatnya (Y) apabila nilai yang dihasilkan < 0,05. Berdasarkan output yang ditampilkan pada Tabel 1 diatas, dapat dilihat bahwa nilai probabilitas $>0,05$ yaitu sebesar 0,729. Nilai $R$-Squared untuk variabel dependen ROA sebesar 0.89 lebih besar dari 0.5, maka menunjukkan korelasi atau hubungan antara 
variable Corporate Social Responsibility dan ROE adalah kuat. Profitabilitas yag diukur dengan variabel dependen ROE dapat dijelaskan oleh variabel CSR yaitu sebesar 89 $\%$. Meskipun hubungan antara kedua variabel kuat tetapi jawaban atas hipotesis variabel Y2 (ROE) sebagai berikut:

H2: Corporate Social Responsibility (CSR) tidak memiliki pengaruh yang signifikan terhadap Return On Equity (ROE)

Hasil penelitian ini sejalan dengan penelitian Fatah dan Haryanto (2016) dan penelitian Heryanto dan Juliarto (2017) yang menemukan bahwa CSR tidak berpengaruh signifikan terhadap ROA dan ROE. Serta berbeda dengan penelitian Karunia dan Dzulkirom (2016) yang menemukan bahwa CSR berpengaruh signifikan terhadap ROA dan ROE.

\section{Kesimpulan dan Saran}

Pengungkapan CSR pada perusahaan Perbankan BUMN yang terdaftar di BEI (Bank Negara Indonesia Tbk, Bank Rakyat Indonesia Tbk, Bank Mandiri Tbk dan Bank Tabungan Negara Tbk) dengan tahun teliti 2017 dan 2018 sudah mengungkapkan program CSR dengan baik di masing-masing laporan tahunan perusahaan walaupun dengan jumlah skor pengungkapan yang berbeda-beda setiap perusahaan. Berdasarkan pada hasil penelitian yang diolah menggunakan aplikasi Eviews, dapat ditarik kesimpulan bahwa: Pertama, CSR tidak memiliki pengaruh yang signifikan terhadap Return On Asset (ROA). Kedua, CSR tidak memiliki pengaruh yang signifikan terhadap Return On Equity (ROE). Secara keseluruhan CSR tidak memiliki pengaruh yang signifikan terhadap profitabilitas baik dari pengukuran Return On Asset (ROA) dan Return On Equity (ROE).

Berdasarkan kajian sebelumnya dikemukakan beberapa saran baik untuk kepentingan praktis maupun untuk pengembangan penelitian selanjutnya sebagai berikut: Diharapkan bagi perusahaan perbankan BUMN untuk lebih memperhatikan kinerja ekonomi dan kinerja lingkungan serta menyeimbangkannya dengan profit yang dimiliki perusahaan. Selain itu disarankan perusahaan perbankan BUMN untuk lebih memperhatikan tenaga kerja atau karyawannya dan hubungan manajemen serta melindungi hak asasi manusia bagi karyawannya, serta lebih peduli terhadap masyarakat sosial. Beberapa saran yang dapat penulis sampaikan untuk peneliti selanjutnya adalah sebagai berikut:1) Penelitian ini hanya terbatas pada perusahaan Perbankan BUMN yang terdaftar di BEI (Bank Negara Indonesia Tbk, Bank Rakyat Indonesia Tbk, Bank Mandiri Tbk dan Bank Tabungan Negara Tbk) sehingga masih banyak objek lain yang bisa diteliti. Untuk penelitian selanjutnya, diharapkan dapat mengembangkan penelitian kepada objek yang berbeda. 2) Penelitian ini hanya menggunakan dua variabel dependen yaitu Return On Asset (ROA) dan Return On Equity (ROE) sebagai pengukur profitabilitas perusahaan. Untuk penelitian selanjutnya dapat menggunakan variabel lain seperti ROI (Return On Investment) atau ROS (Return On Sales). 3) Penelitian ini hanya menggunakan data dua tahun yaitu 2017 dan 2018. Untuk penelitian selanjutnya diharapkan dapat memperpanjang waktu pengamatan sehingga penelitian dapat digeneralisasi dan menggunakan data yang lebih spesifik, agar hasil penelitian lebih lengkap dan akurat.

\section{REFERENSI}

[1] Brigham dan Houston, 2006. Dasar-dasar Manajemen Keuangan. Salemba Empat. Jakarta.

[2] Fahmi, Irham. 2015. Manajemen Perbankan Konvesional \& Syariah. Jakarta: Mitra Wacana Media.

[3] Fahmi, Irham. 2016. Pengantar Manajemen Keuangan Teori Dan Soal Jawab. Bandung: ALFABETA.

[4] Fatah Karina dan Haryanto Melinda. (2016). Pengaruh Pengungkapan Corporate Social Responsibility Terhadap Profitabilitas Perusahaan : Studi Empiris Pada Perusahaan Manufaktur Sektor Industri Dasar Dan Kimia Yang Terdaftar Di Bursa Efek Indonesia. Jurnal Ekonomi dan Bisnis EKONOMIS. Vol. 10, Nomor 2, September 2016. Hal: 1-20

[5] Harrison, Walter. T. Jr. et.al. 2012. Akuntansi Keuangan: International 
Financial Reporting Standars.

Penerjemah Gina Gania. Jakarta: Erlangga.

[6] Heryanto Robby, Juliarto Agung. 2017. Pengaruh corporate social responsibility terhadap profitabilitas perusahaan (studi empiris pada perusahaan manufaktur yang terdaftar di bursa efek indonesia periode 2014- 2015). Diponegoro journal of accounting. Vol 6, nomor 4. Hal 1-8

[7] Kamaludin. 2010. Pengaruh Pengungkapan Corporate Social Responsibility Terhadap Profitabilitas dan Reputasi Perusahaan (Studi Empiris Pada Perusahaan yang Terdaftar di Bursa Efek Indonesia). Naskah publikasi.

[8] Karunia Mega dan Dzulkirom Moch. (2016). Pengaruh Corporate Social Responsibility (CRS) Terhadap Profitabilitas Perusahaan (Studi Pada Sektor Industri Barang Konsumsi Yang Terdaftar Di Bursa Efek Indonesia Periode 2013-2014). Jurnal Administrasi Bisnis (JAB), Vol. 38 No.2 September 2016. Hal: 16-22

[9] Kasmir. 2012. Analisis Laporan Keuangan. Jakarta: Rajagrafindo Persada

[10] Kiroyan, Noke, 2006. "Good Corporate Governance (GCG) dan Corporate Social Responsibility (CSR) Adakah Kaitan di Antara Keduanya?" Economics Business Accounting Review. Edisi III. SeptemberDesember: $45-58$.

[11]Lindrawati, Felicia dan Budianto, 2008. "Pengaruh Corporate Social Responsibility Terhadap Kinerja Keuangan Perusahaan yang Terdaftar Sebagai 100 Best Corporate Citizens oleh KLD Research and Analytics," Majalah Ekonomi. Tahun XVIII, No. 1 April : 6683

[12] Pramana, i. G. A., \& yadnyana, i. K. 2016. Pengaruh Corporate Social Responsibility Terhadap Kinerja pada Perusahaan Manufaktur. E-jurnal
Akuntansi Universitas Udayana. Vol.16 no.3. Hal 1964-1988

[13] Romadhika Muhammad, Majidah. 2019. Pengaruh biaya Corporate Social Responsibility terhadap profitabilitas (studi kasus pada perusahaan sektor makanan dan minuman yang terdaftar di bursa efek indonesia pada tahun 20122017). Jurnal E-proceeding of management : vol.6. no.2. Hal 3077-3082

[14]Rosdwianti, Dzulkirom dan Zahroh. 2016. Pengaruh Corporate Social Responsibility (CSR) Terhadap Profitabilitas Perusahaan (Studi pada sektor industri barang konsumsi yang terdaftar di bursa efek indonesia periode 2013-2014). Jurnal administrasi bisnis (jab). Vol. 38 No.2. Hal 16-22

[15] Rudito, B. 2013. CSR Corporate Social Responsibility. Sumatera Utara: Rekayasa Sains,

[16]Rusdianto, Ujang. 2013. CSR Communication A Framwork for PE Practitioners. Yogyakarta: Graha Ilmu

[17] Samryn, L. M. 2014. Pengantar Akuntansi Mudah Membuat Jurnal dengan Pendektan Siklus Transaksi. Jakarta: PT Rajagrafindo Persada.

[18] Singarimbun, efendi. 1990. Metode penelitian survei. Bandung: mandar maju

[19] Sugiyono. 2012. Metode Penelitian Kombinasi Mixed Methods. Bandung. Alfabeta.

[20] Syamsuddin, Lukman. 2013. Manajemen Keuangan Perusahaan. Jakarta: PT.Raja Grafindo Persada.

[21] Untung, Budi Hendrik. 2009. Corporate Social Responsibility. Jakarta: Sinar Grafika

[22] Walsh, c. (2004). Key management : rasio-rasio manajemen penting penggerak dan pengendali bisnis. Jakarta : erlangga.

[23] Wibisono, yusuf. 2007. Membedah konsep dan aplikasi csr. Gresik. Fascho publishing. 